\section{Seediness of Native and Improved Rabbiteye Blueberry}

Paul M. Lyrene

Horticultural Sciences Department, University of Florida, Gainesville, FL 32611

Additional index words. Vaccinium ashei, blueberry breeding
Rabbiteye blueberry (Vaccinium ashei Reade) is a vigorous, hexaploid species with a restricted native range that includes parts of western Florida, southern Alabama, southeastern Georgia, and southeastern South Carolina. The first record of rabbiteye blueberry cultivation dates to 1887 when a small planting was made near Whitehouse, Fla., with plants from nearby forests (Cochran, 1941). By 1930, more than 1000 ha of rabbiteye blueberries, comprised mostly of unselected native plants dug from river valleys of northern Florida during winter, had been planted in Florida (Lyrene, 1979). By the time most of these plantings came into production, the rabbiteye blueberry industry was already failing. Fruit of the unselected plants were often dark, seedy, gritty, thick-skinned, and sometimes astringent compared to the highbush ( $V$. corymbosum L.) and lowbush ( $V$. angustifolium Ait.) berries to which northern blueberry markets were accustomed. started in 1925 when a collection of wild plants from Florida and Georgia was planted at the Georgia Coastal Plain Expt. Station in Tifton (Moore, 1966). Since then, many improved rabbiteye cultivars have been released following one, two, or three cycles of selection for improved fruit quality and higher yields. These cultivars seem to be less seedy and to have better texture than the wild stocks from which they were bred. My objective was to document the progress of reducing berry seediness that has been made through breeding

From 1978 to 1984 , several thousand native rabbiteye blueberry plants were examined in their native habitats (Florida, Georgia, and Alabama) at the time of fruit ripening, and $\approx 100$ were selected for propagation by cuttings. Plants were selected based on fruit size, fruit quality, and plant health and vigor. Rooted cuttings were planted in two- or three-plant plots at the Univ. of Florida Horticultural Unit between 1979 and 1985. The plants were from three wild populations: West Florida (the Florida panhandle between the Apalachicola River and the Alabama border west of Pensacola, numerous sites represented in the publication 9 Dec. 1993. Univ. of Florida Journal Series no. R-03370. The cost of publishing this paper was defrayed in part by the payment of page charges.Under postal regulations, this paper thereforemustbehereby marked advertisement solely to indicatethis fact.
Improvement of the rabbiteye blueberry improved rabbiteye cultivars.

Receivedforpublication7 Sept. 1993. Accepted for sample), Canochee River (Canochee River and other small rivers in southeastern Georgia near Claxton), and St. Marys River (St. Marys River drains the southeastern comer of the Okefenokee Swamp and forms the boundary between northeastern Florida and southeastern Georgia; most plants were collected along the river between Macclenny, Fla., and St. George, Ga.).

In 1992,40 berries were harvested during of the 60 native rabbiteye plants and from 18 cultivars and advanced selections representing the cultivated rabbiteye gene pool. All plants were growing on a 2-ha parcel of land at a research farm in Gainesville, Fla. Many bumblebees (Bombus spp.) and southeastern blueberry bees (Habropoda laboriosa F.) were present in the field during flowering.

Berries were weighed immediately after harvest. Within each of the four populations (West Florida, Canochee River, St. Marys River, and cultivated), clones were randomly grouped by threes, creating 120-berry composites with 40 berries from each clone. The seeds were extracted from each sample with a food blender, separated from other berry components with water, and dried on a bench top for 1 week before they were weighed. Mean berry fresh weight and the dried seed weight: berry fresh weight ratio were calculated for each sample. Mean values for the four populations were calculated and compared using pairwise $t$ tests.

Berries of cultivars were heavier than those of native populations (Table 1). The three wild populations did not differ significantly from each other in berry weight; the overall mean was $714 \mathrm{mg}, 36 \%$ of the mean berry weight of the cultivars.

Contrary to expectation, seed weight per berry was no higher for native clones than for cultivars. In fact, the native clones from the St. Marys River population averaged significantly lower seed weight per berry than cultivars.

The seed weight : fruit weight ratio was

Table 1. Mean berry fresh weight, weight of dried seeds per berry, and seed weight : berry weight ratios for four populations of rabbiteye blueberry.

\begin{tabular}{lcccc}
\hline \hline Population & $\begin{array}{c}\text { No. } \\
\text { composites }\end{array}$ & $\begin{array}{c}\text { Mean berry } \\
\text { fresh wt }(\mathrm{mg})\end{array}$ & $\begin{array}{c}\text { Mean seed dry } \\
\text { wt/berry }(\mathrm{mg})\end{array}$ & $\begin{array}{c}\text { Seediness } \\
\text { index }(\%)^{\mathrm{y}}\end{array}$ \\
\hline West Florida & 8 & $752 \mathrm{a}^{\mathrm{x}}$ & $21.6 \mathrm{ab}$ & $2.87 \mathrm{~b}$ \\
Canochee River & 6 & $716 \mathrm{a}$ & $24.3 \mathrm{ab}$ & $3.42 \mathrm{~b}$ \\
St. Marys River & 6 & $673 \mathrm{a}$ & $19.0 \mathrm{a}$ & $2.93 \mathrm{~b}$ \\
Cultivated & 6 & $2005 \mathrm{~b}$ & $26.1 \mathrm{~b}$ & $1.33 \mathrm{a}$ \\
\hline
\end{tabular}

Each composite contains three clones, 40 berries per clone.

'Seed dry weight per berry divided by berry fresh weight.

${ }^{\times}$Means separation at $P \leq 0.01$ by pairwise $t$ tests. vars, both highbush and rabbiteye, and can, along with seeds, contribute to the sensation of berry grittiness (Eck, 1966). Reductions in fruit sclerid content may have occurred as a result of selection for improved fruit quality in rabbiteye blueberry, but I did not investigate that aspect. Selection for reliable fruiting probably has prevented any reduction in seed count per berry in cultivated varieties despite selection for improved texture; under most conditions, seed are necessary for retention and normal development of the rabbiteye berry.

Growers have expressed interest in the development of rabbiteye blueberry cultivars with smaller fruit for processing markets. Processors prefer the small berries of the lowbush blueberry. Small berries are more suitable in pancakes, muffins, and other baked products than the larger berries of the cultivated highbush and rabbiteye cultivars. Consequently, wild lowbush blueberries normally bring higher prices on the processing market than cultivated blueberries. My data indicate that care must be taken in breeding smaller-fruited rabbiteye cultivars to avoid an increase in the seed : fruit ratio. The use of gibberellic acid sprays in conjunction with solid-block plantings of a single self-incompatible rabbiteye clone could produce small-fruited rabbiteye berries with few seeds (Eck, 1988).

\section{Literature Cited}

Cochran, H. 1941. Blueberries, with special referencetoFloridaculture.Florida State Dept. Agr., Tallahassee, Bul. 33, New Series.

Eck, P. 1966. Botany, p. 14-44. In: P. Eck and N.F. Childers (eds.). Blueberry culture. Rutgers Univ. Press, New Brunswick, N.J.

Eck, P. 1988. Blueberry science. Rutgers Univ. Press, New Brunswick, N.J.

Lyrene,P.1979.Therabbiteyeblueberry industry in Florida(1887 to 1930) with notes on the current status of abandoned plantations. Econ. Bet. $33: 237-243$

Moore, J.N. 1966. Breeding, p. 45-74. In: P. Eck and N.F. Childers (eds.). Blueberry culture. Rutgers Univ. Press, New Brunswick, N.J. the first part of the ripening season from each

lower for the cultivars than for the native clones. Again, the three populations of native clones did not differ significantly from each other, and they averaged 3.0770 seed compared to $1.33 \%$ for cultivars.

The apparent reduction in seediness and at least some of the associated improvement in berry texture achieved by 1 to 4 cycles of recurrent selection in rabbiteye blueberry apparently have come from increased berry size, accompanied by little or no change in seed content per berry. Sclerids, or stone cells, are present in the fruit of many blueberry culti-

HortSCience, Vol. 29(6), June 1994 